\title{
Validity of a Self-Administered Food Frequency Questionnaire against 7-day Dietary Records in Four Seasons
}

\author{
Kyong-Yeon LeE $^{1}$, Kazuhiro UCHIDA ${ }^{2}$, Tomoko SHIROTA ${ }^{2}$ and Suminori Kono ${ }^{1, *}$ \\ ${ }^{1}$ Department of Preventive Medicine, Faculty of Medical Sciences, Kyushu University, \\ Higashi-ku, Fukuoka 812-8582, Japan \\ ${ }^{2}$ Division of Food and Nutrition, Nakamura-Gakuen Junior College, \\ Jonan-ku, Fukuoka 814-0198, Japan
}

(Received March 16, 2002)

\begin{abstract}
Summary The validity of a food frequency questionnaire (FFQ) was evaluated against four 7-d diet records among 23 men aged 27-70 y. Volunteer women recorded the amounts of all foods and beverages consumed by their husbands or fathers over a period of $7 \mathrm{~d}$ in four consecutive seasons in 1997 and 1998, and a self-administered FFQ was answered by each man after completion of the fourth diet record. The diet record was kept in accordance with the method used for Japan's National Nutrition Survey. The FFQ ascertained frequencies and amounts of consumption of rice, bread, noodles, green tea, and coffee; consumption frequency of 35 food items; and consumption frequency and amount of five alcoholic beverages. As for most nutrients and foods, mean intakes estimated by the FFQ were lower than those estimated from the diet record. Crude intake of nutrients showed fairly good agreement between the two methods in terms of Pearson's correlation coefficient $(r>0.5)$, except for total energy $(r=0.23)$, fat $(r=0.36)$, and vitamin A $(r=0.29)$. The adjustment for energy intake generally reduced the correlation; the reduction being fairly large for fat intake and vitamin A ( $r=0.19$ for both). There was generally good agreement for the intake of foods and beverages with exceptions for fats/oils (Spearman correlation coefficient, $\left.r_{\mathrm{s}}=0.30\right)$ and other vegetables $\left(r_{\mathrm{s}}=0.35\right)$. The highest correlation was observed for alcoholic beverages $\left(r_{\mathrm{s}}=0.91\right)$, bread $\left(r_{\mathrm{s}}=0.80\right)$, and fruits $\left(r_{\mathrm{s}}=0.77\right)$. An FFQ covering a limited number of common foods may be useful in assessing the relative position of an individual's habitual consumption of foods and nutrients; however, the instrument generally underestimates absolute intake.
\end{abstract}

Key Words validity, food frequency questionnaire, diet record, Japanese men

Much attention has been drawn to the role of diet in the prevention of cancer and cardiovascular diseases over the past decades (1-3). It is important to measure the habitual, long-term intake of foods and nutrients in order to study the relationship between diet and chronic diseases $(3,4)$. Of the several methods for measuring an individual's intake of foods and nutrients, the food frequency questionnaire (FFQ), with and without partial quantitation, has been used most frequently in epidemiologic studies mainly because of easy administration in a large population $(3,4)$. While a quantitative estimation of food and nutrient intake by FFQ has been done successfully for epidemiologic studies of chronic diseases such as cancer and cardiovascular diseases in Europe and North America (5-14), most epidemiologic studies on diet and disease in Japan have been based on only the frequency of consuming a limited number of food items and groups (15-21). Simple or semiquantitative FFQs have been developed very recently to estimate the habitual intake of foods and nutrients quantitatively in Japan (22-26). We developed a self-adminis-

* To whom correspondence should be addressed.

E-mail: skono@phealth.med.kyushu-u.ac.jp tered FFQ for use in the Self Defense Forces Health Study (27-29), in which our aim was to examine the relationship of dietary factors to colorectal adenomas. This paper describes the validity of our FFQ as compared to the diet record method.

\section{MATERIALS AND METHODS}

Subjects. A total of 24 volunteer women were recruited to participate in the study. They were asked to record the amounts of foods and beverages consumed by their husbands or fathers for a 7-d period four times in $1 \mathrm{y}$. The first record was done in July to August 1997; the second in October to November 1997; the third in January to February 1998; and the fourth in April to May 1998. A gratuity of 5,000 Japanese yen was awarded after the completion of each 7-d record. One woman withdrew before the third record, and the remaining 23 completed four records for their husbands $(n=18)$ or fathers $(n=5)$. The participating women were research nurses $(n=10)$ and clerical workers $(n=2)$ at the Department of Preventive Medicine, Kyushu University and their acquaintances $(n=11)$, who were housewives.

Dietary records. Detailed instruction was given per- 
sonally as to how to record the foods and beverages before implementing the first record; the instruction was in accordance with the method used for Japan's National Nutrition Survey (30). In brief, amounts of foods used for each dish and of beverages consumed for breakfast, lunch, supper, and between-meal snacks and drinks were weighed or alternatively estimated. As for foods consumed outside of the home, in the absence of the woman in charge of recording, the amounts of such foods and beverages were elicited by inquiring to the husband or father. Dietetic scale apparatus were provided when needed. A set of forms for recording the diet for $7 \mathrm{~d}$ was given with an example of a recording. As for the second to fourth records, the instructions and record forms were mailed or handed to each participating woman. The participating women were requested not to inform their husbands or fathers of the future administration of the FFQ. For each 7-d record, the record forms were inspected for completeness by an expert dietitian, and ambiguous records were solved by asking questions to participating women via telephone or in person.

Diet records were analyzed to calculate the intake of 12 nutrients and 23 food groups on the basis of the Food Composition Table, Version 4 (31) using software developed by one of the authors (T. Shirota). For reported foods that were not in the Food Composition Table, an expert dietitian chose the most appropriate substitute foods from the table. Version 5 of the Food Composition Table was published in 2000 (32), but the software did not incorporate the new version. Green tea and coffee consumption were enumerated manually because the amount of an individual food or beverage was not reported in the software.

FFQ. A self-administered FFQ was answered by each man in July to August 1998 after completion of the fourth diet record. The self-administered questionnaire inquired about the average consumption of 40 food items and five types of alcoholic beverage in the past year (see Appendix 1). The 40 food items were determined on the basis of previous experiences with dietary surveys done by one of the authors (33). Both consumption frequency and amount were ascertained regarding rice, noodles, bread, green tea, and coffee. Individuals answered the frequency of consuming rice, noodles, and bread by choosing one of five categories (almost null, once a week, 2-3 times a week, 4-5 times a week, and almost daily), and those that consumed a food item once or more per week reported the amount consumed per day using conventional units (e.g., number of bowls for rice and noodles, number of slices for bread). Tea and coffee consumption were ascertained by using closed-ended questions (almost null, one cup per week, 2-3 cups per week, 4-5 cups per week, and almost daily) and open-ended questions inquiring to those who answered "almost daily" the number of cups consumed per day. The frequency of consumption of the remaining 35 items was ascertained using six categories (almost null, once a week, 2-3 times a week, 4-5 times a week, almost once per day, and two times or more per day). As for alcoholic beverages, the frequency and quantity were ascertained for sake, shochu, beer, spirits, hard liquor, and wine separately. Six response categories (no use, 1-3 times per month, 1-2 times per week, 3-4 times per week, 5-6 times per week, and almost daily) were prepared for each alcoholic beverage, and the average amount of each beverage consumed per occasion was reported.

To calculate the intake of nutrients and food groups from the FFQ, the portion size of each food item and the proportions of individual composite foods were determined (see Appendix 2). Five specific food items (onion, broiled fish, broiled meat, broiled poultry, and raw vegetables) were not used for calculating the intake of nutrients and food groups because broader food items were ascertained separately. For most of the food items, portion sizes and proportions of individual composite foods were based on data from a previous survey (33). As for several other food items, they were determined on the basis of information from various sources including recipe books (34-37).

Statistical analysis. Mean and standard deviation are shown in terms of absolute intake of nutrients and foods. Pearson correlation coefficients were used to examine the agreement between nutrient intake derived from the FFQ and that from the diet record. The distributions of most nutrients were skewed toward higher values, and thus natural-log transformation was done for all the nutrient variables. Nutrient intake adjusted for total energy intake was calculated by the Willett method using the residuals from a regression line (38). The agreement for the food groups was evaluated using Spearman's rank correlation coefficient. Further, the subjects were classified into three groups at the tertiles of the distribution in terms of FFQ-based intake and record-based intake each, and the agreement of categories was evaluated by weighted kappa statistics. All statistical computations were done using SAS Version 6.12 (SAS Institute, Inc., Cary, NC, USA).

\section{RESULTS}

The average daily intake of energy and nutrients estimated from the FFQ were generally lower than those derived from the 28-d record (Table 1 ). The average intakes reported for energy, protein, and fat were about $40 \%$ lower in the questionnaire-based estimates, and the intakes reported for carbohydrates and dietary fiber were approximately 30\% lower. Questionnaire-based intake was also lower than that estimated from the diet records for some, but not all, food groups (Table 2). While the intakes reported for fish, meat, poultry, eggs, and vegetables were 40-60\% lower in the questionnaire than in the diet record, the questionnaire-based intakes of cereals, soy products, green tea, and coffee did not differ greatly from the intakes estimated using the diet records. The average alcohol intake estimated by the two methods was almost identical.

Pearson correlation coefficients between nutrient intake estimated from the diet records and questionnairebased nutrient intake are shown in Table 3. While the 
Table 1. The average daily intake of energy and nutrients estimated from the diet record and food frequency questionnaire (FFQ).

\begin{tabular}{lccc}
\hline & \multicolumn{2}{c}{ Mean (SD) } & Ratio of FFQ to record \\
\cline { 2 - 3 } Nutrient (unit) & Diet record & FFQ & 0.61 \\
Energy (kcal) & $2,251(285)$ & $1,366(169)$ & 0.55 \\
Protein (g) & $89(10)$ & $49(6)$ & 0.62 \\
Fat (g) & $67(15)$ & $41(10)$ & 0.68 \\
Carbohydrates (g) & $266(51)$ & $181(38)$ & 0.72 \\
Total fiber (g) & $11.1(2.6)$ & $8.0(2.0)$ & 0.74 \\
Soluble dietary fiber (g) & $1.9(0.6)$ & $1.4(0.5)$ & 0.71 \\
Insoluble dietary fiber (g) & $9.2(2.1)$ & $6.5(1.6)$ & 0.47 \\
Vitamin A (IU) & $2,903(1,086)$ & $1,368(483)$ & 0.56 \\
Vitamin C (mg) & $104(36)$ & $58(23)$ & 0.58 \\
Calcium (mg) & $573(150)$ & $330(106)$ & 0.49 \\
Iron (mg) & $12(2)$ & $6(1)$ & 0.60 \\
Potassium (mg) & $2,905(549)$ & $1,742(423)$ &
\end{tabular}

Table 2. Absolute intake $(\mathrm{g} / \mathrm{d})$ of selected food groups estimated from the diet record and food frequency questionnaire (FFQ).

\begin{tabular}{|c|c|c|c|}
\hline \multirow{2}{*}{ Food and beverage } & \multicolumn{2}{|c|}{ Mean (SD) } & \multirow{2}{*}{ Ratio of FFQ to record } \\
\hline & Diet record & FFQ & \\
\hline Cereals & $485(100)$ & $412(86)$ & 0.85 \\
\hline Rice & $352(119)$ & $306(98)$ & 0.87 \\
\hline Noodles & $84(37)$ & $64(44)$ & 0.77 \\
\hline Bread & $38(32)$ & $42(52)$ & 1.11 \\
\hline Confectioneries & $24(21)$ & $15(13)$ & 0.63 \\
\hline Fats and oils & $20(8)$ & $16(8)$ & 0.83 \\
\hline Fish & $77(35)$ & $33(15)$ & 0.43 \\
\hline Meat & $112(42)$ & $48(17)$ & 0.43 \\
\hline Poultry & $32(20)$ & $13(7)$ & 0.40 \\
\hline Eggs & $41(17)$ & $27(20)$ & 0.66 \\
\hline Dairy products & $90(83)$ & $106(99)$ & 1.18 \\
\hline Seaweed & $5(4)$ & $1(1)$ & 0.13 \\
\hline Total vegetables & $266(61)$ & $165(75)$ & 0.62 \\
\hline Green-yellow vegetables ${ }^{1}$ & $58(24)$ & $45(21)$ & 0.78 \\
\hline Other vegetables $^{1}$ & $193(36)$ & $110(64)$ & 0.57 \\
\hline Pickled vegetables & $14(16)$ & $10(11)$ & 0.73 \\
\hline Tofu & $50(20)$ & $43(23)$ & 0.86 \\
\hline Fermented soybeans & $12(8)$ & $10(10)$ & 0.86 \\
\hline Soy paste & $10(5)$ & $8(2)$ & 0.82 \\
\hline Fruits & $67(80)$ & $56(70)$ & 0.82 \\
\hline Green tea & $150(129)$ & $126(170)$ & 0.84 \\
\hline Coffee & $258(179)$ & $318(282)$ & 1.23 \\
\hline Alcoholic beverages ${ }^{2}$ & $30(30)$ & $32(42)$ & 1.06 \\
\hline
\end{tabular}

\footnotetext{
${ }^{1}$ Not including pickled vegetables.
}

${ }^{2}$ Amount in ethanol (g).

intake of total energy, fat, and vitamin A showed relatively low correlations, other macronutrients and micronutrients showed fairly high correlations. The correlation coefficients for energy-adjusted nutrient intake were generally smaller than those for crude intake. The correlation coefficients for fat and vitamin A were much attenuated when energy-adjusted intake was used.

As for most of the food groups in the study, the corre- lation between questionnaire-based and record-based intake was fairly good (Table 4). The items "fats/oils" and "vegetables other than green-yellow vegetables" had Spearman's correlation coefficients of less than 0.4. The correlation coefficients for four food groups were greater than 0.7: bread $\left(r_{\mathrm{s}}=0.80\right)$, fruits $\left(r_{\mathrm{s}}=0.77\right)$, coffee $\left(r_{\mathrm{s}}=0.75\right)$, and alcohol $\left(r_{\mathrm{s}}=0.91\right)$. Kappa statistics also showed a fairly good agreement between the two methods, except for cereals (0.29), confectioneries 
Table 3. Pearson's correlation coefficients of energy and nutrient intake between the diet record and food frequency questionnaire.

\begin{tabular}{|c|c|c|}
\hline Nutrient (unit) ${ }^{1}$ & Crude $^{2}$ & Energy-adjusted $^{2}$ \\
\hline Energy (kcal) & 0.23 & - \\
\hline Protein $(\mathrm{g})$ & 0.58 & 0.44 \\
\hline Fat $(\mathrm{g})$ & 0.36 & 0.19 \\
\hline Carbohydrates (g) & 0.57 & 0.45 \\
\hline Total fiber $(\mathrm{g})$ & 0.57 & 0.56 \\
\hline Soluble dietary fiber $(\mathrm{g})$ & 0.62 & 0.52 \\
\hline Insoluble dietary fiber $(\mathrm{g})$ & 0.55 & 0.56 \\
\hline Vitamin A (IU) & 0.29 & 0.19 \\
\hline Vitamin C (mg) & 0.51 & 0.35 \\
\hline Calcium (mg) & 0.55 & 0.52 \\
\hline Iron (mg) & 0.55 & 0.31 \\
\hline Potassium (mg) & 0.72 & 0.63 \\
\hline
\end{tabular}

${ }^{1}$ All variables were transformed to the scale of natural logarithm.

${ }^{2} p<0.05$ for correlation coefficient $>0.41, p<0.01$ for correlation coefficient $>0.53$.

(0.33), fats/oils (0.14), and other vegetables (0.30).

\section{DISCUSSION}

The dietary questionnaire used in the present study underestimated the absolute intake of nutrients and foods, but fairly adequately predicted the relative position of an individual's long-term intake of most nutrients and foods. The underestimation of amounts was probably due to the limited number of food items in the questionnaire. It is also possible that the portion size assigned to some of the food items may have been lower than the average portion size consumed by the study subjects. It has been reported that nutrient and food intake measured using FFQs is generally lower than estimates made on the basis of diet records or detailed diet histories in both Western countries $(5,9,10,12-14)$ and Japan (24).

In the present study, most of the nutrients and foods showed fairly good correlation between record and questionnaire except for the items of total energy, fat intake, vitamin $\mathrm{A}$, and fats/oils. The correlation coefficient of 0.23 for total energy intake was much smaller than reported in some of the previous studies using a semiquantitative FFQ $(11,13,14)$, but not materially less than the values reported in other studies $(5,7,10$, 12) in Western countries. The correlation coefficients for total energy were 0.21 in one Japanese study (26) and 0.45 in another study based on a semiquantitative FFQ in Japan (23). In the present questionnaire, the quantity was elicited only regarding rice, bread, noodles, and alcoholic beverages as well as green tea and coffee. It would be necessary to ascertain the portion size of energy-dense, common foods such as meat, poultry, and confectioneries to improve the estimation of energy intake on the basis of the questionnaire. A major source of fat intake in the Japanese diet is vegetable oils used for cooking (deep-frying, and pan-frying); one
Table 4. Spearman's correlation coefficients and weighted kappa statistics of individual food intake between the diet record and food frequency questionnaire.

\begin{tabular}{|c|c|c|}
\hline Food and beverage & $\begin{array}{l}\text { Spearman's } \\
\text { correlation }^{1}\end{array}$ & $\begin{array}{l}\text { Weighted } \\
\text { kappa }^{2}\end{array}$ \\
\hline Cereals & 0.51 & 0.29 \\
\hline Rice & 0.56 & 0.54 \\
\hline Noodles & 0.47 & 0.46 \\
\hline Bread & 0.80 & 0.72 \\
\hline Confectioneries & 0.40 & 0.33 \\
\hline Fats and oils & 0.30 & 0.14 \\
\hline Fish & 0.51 & 0.38 \\
\hline Meat & 0.48 & 0.44 \\
\hline Poultry & 0.59 & 0.44 \\
\hline Eggs & 0.69 & 0.55 \\
\hline Dairy products & 0.58 & 0.56 \\
\hline Seaweed & 0.56 & 0.47 \\
\hline Total vegetables & 0.40 & 0.35 \\
\hline Green-yellow vegetables 3 & 0.40 & 0.37 \\
\hline Other vegetables ${ }^{3}$ & 0.35 & 0.30 \\
\hline Pickled vegetables & 0.58 & 0.42 \\
\hline Tofu & 0.52 & 0.41 \\
\hline Fermented soybean & 0.52 & 0.53 \\
\hline Soy paste & 0.61 & 0.51 \\
\hline Fruits & 0.77 & 0.62 \\
\hline Green-tea & 0.64 & 0.58 \\
\hline Coffee & 0.75 & 0.71 \\
\hline Alcoholic beverages ${ }^{4}$ & 0.91 & 0.70 \\
\hline
\end{tabular}

${ }^{1} p<0.05$ for correlation coefficient $>0.42, p<0.01$ for correlation coefficient $>0.53$.

${ }^{2}$ All variables were classified into three categories.

${ }^{3}$ Not including pickled vegetables.

${ }^{4}$ Amount in ethanol (g).

study showing that approximately $15 \%$ of fat intake is derived from vegetables oils used for cooking (39). It is difficult to ascertain the exact amount of oil used for cooking. The present study ascertained the frequency of deep-fried and pan-fried foods, and $10 \mathrm{~g}$ and $5 \mathrm{~g}$ of vegetable oil were assigned to one serving of deep-fried or pan-fried foods, respectively. Admittedly, this method was crude for estimating the amount of oil consumed. The poor estimate for oil intake probably resulted in a relatively weak correlation for fat intake, and consequently total energy intake, between the dietary record and FFQ.

The use of energy-adjusted nutrient intake did not increase the correlation between the estimates from the diet record and those from the questionnaire. In general, correlation coefficients between the diet record and FFQ were slightly higher for the energy-adjusted intake of nutrients than for unadjusted (raw) nutrient intake in studies in Europe and North America (5, 7, 912). These results indicate that the reduction in correlated measurement error for total calories and nutrients exceeds the reduction in between-individual variations of nutrient intake resulting from adjustment for energy intake (38). In the present study, fat intake showed a much smaller correlation coefficient between the two 
methods after adjustment for energy intake. The variation of fat intake was only slightly attenuated by adjustment for energy intake; the coefficient of variation of energy-adjusted fat intake in the scale of natural logarithm being $3.8 \%$, while that of unadjusted fat intake was $4.9 \%$. The measurement error in the FFQ and/or diet record may have been greater for total energy intake than for fat intake. Two validation studies in Japan also reported that the correlation coefficient for energyadjusted fat intake was lower than that for crude fat intake $(23,24)$. The correlation coefficients for crude and energy-adjusted nutrients other than fat in the present study were almost the same in magnitude as reported in other Japanese studies $(23,24,26)$.

Diet records have been regarded as the best reference method for validating an FFQ. However, we have no exact information regarding the thoroughness of diet records. There may have been some inaccuracy in estimations even based on the diet record. The period of recording is an important factor for determining the accuracy of habitual nutrient and food intake, especially when intake varies according to season. The method of taking four 7-d records over a period of $1 \mathrm{y}$ was used in the validation of a semiquantitative FFQ used in the Nurses' Health Study (9). Two 7-d dietary records were employed to validate another semiquantitative FFQ given in the Health Professionals Follow-up Study (10) and a FFQ with a portion-size picture booklet in the Alpha-Tocophenol Beta Carotene Cancer Prevention Study (11). The semiquantitative FFQ used in a Dutch prospective study was validated by making a comparison with three $3-d$ records carried out 4-5 months apart (13). In Japan, Wakai et al. (22) validated their FFQ using four 4-d records which were obtained at intervals of $3 \mathrm{mo}$, and Tokudome et al. (23) repeated a 1wk record four times over a $1-\mathrm{y}$ period to validate a semiquantitative FFQ. While a record of $7-14 \mathrm{~d}$ in length has been considered adequate to measure most of the diet in Western populations $(5,7,10,12,13)$, it is not certain how many days are needed to estimate the habitual intake of nutrients and foods in the Japanese diet. In this regard, the use of four 7 -d records in the present study is noteworthy.

Another methodological advantage in the present study is that female spouses (or daughters) recorded the diet of their husbands (or fathers). In previous studies using diet records $(5-7,9-14,22-24,26)$, participants themselves recorded their diet and answered a dietary questionnaire. The correlation between the FFQ and diet record observed in these studies probably overestimated the validity because persons participating in the diet record may have been more interested in their diet; and therefore may have recorded the diet and administered the questionnaire more accurately.

The present questionnaire was developed to primarily examine the relation of food and nutrient intake to colorectal adenomas in middle-aged men of the Self Defense Forces. It may be difficult to address the role of fat intake in the occurrence of colorectal adenomas because the crude measurement necessarily attenuates the true association.

In conclusion, the FFQ covering a limited number of common food items may be useful in assessing the relative position of an individual's habitual consumption of foods and nutrients while the instrument generally underestimates absolute intake.

\section{REFERENCES}

1) Committee on Diet and Health, National Research Council. 1989. Diet and Health. Implications for Reducing Chronic Disease Risk. National Academy Press, Washington, DC.

2) World Cancer Research Fund and American Institute for Cancer Research. 1997. Food, Nutrition and the Prevention of Cancer. A Global Perspective. American Institute for Cancer Research, Washington, DC.

3) Willett WC. 1998. Nutritional Epidemiology, Second edition. Oxford University Press, New York.

4) Thompson FE, Byers T. 1994. Dietary assessment resource manual. J Nutr 124 (Suppl 11): S2245-S2317.

5) Tjønneland A, Overvad K, Haraldsdottir J, Bang S, Ewertz M, Jensen OM. 1991. Validation of a semiquantitative food frequency questionnaire developed in Denmark. Int J Epidemiol 20: 906-912.

6) Block G, Thompson FE, Hartman AM, Larkin FA, Guire KE. 1992. Comparison of two dietary questionnaires validated against multiple dietary records collected during a 1-year period. J Am Diet Assoc 92: 686-693.

7) Jain M, Howe GR, Rohan T. 1996. Dietary assessment in epidemiology. Comparison of a food frequency and a diet history questionnaire with a 7-day food record. Am J Epidemiol 143: 953-960.

8) Kaaks R, Slimani N, Riboli E. 1997. Pilot phase studies on the accuracy of dietary intake measurements in the EPIC project. Overall evaluation of results. Int $J$ Epidemiol 26 (Suppl 1): S26-S36.

9) Willett WC, Sampson L, Stampfer MJ, Rosner B, Bain C, Witschi J, Hennekens CH, Speizer FE. 1985. Reproducibility and validity of a semiquantitative food frequency questionnaire. Am J Epidemiol 122: 51-65.

10) Rimm EB, Giovannucci EL, Stampfer MJ, Colditz GA, Litin LB, Willett WC. 1992. Reproducibility and validity of an expanded self-administered semiquantitative food frequency questionnaire among male health professionals. Am J Epidemiol 135: 1114-1126.

11) Pietinen P, Hartman AM, Haapa E, Räsänen L, Haapakoski J, Palmgren J, Albanes D, Virtamo J, Huttunen JK. 1988. Reproducibility and validity of dietary assessment instruments. I. A self-administered food use questionnaire with a portion size picture booklet. Am J Epidemiol 128: 655-666.

12) Männistö S, Virtanen M, Mikkonen T, Pietinen P. 1996. Reproducibility and validity of a food frequency questionnaire in a case-control study on breast cancer. J Clin Epidemiol 49: 401-409.

13) Goldbohm RA, van den Brandt PA, Brants HAM, van't Veer P, Al M, Sturmans F, Hermus RJJ. 1994. Validation of a dietary questionnaire used in a large-scale prospective cohort study on diet and cancer. Eur J Clin Nutr $\mathbf{4 8}$ : 253-265.

14) Martin-Moreno JM, Boyle P, Gorgojo L, Maisonneuve P, Fernandez-Rodriguez JC, Salvini S, Willett WC. 1993. Development and validation of a food frequency questionnaire in Spain. Int J Epidemiol 22: 512-519.

15) Kono S, Ikeda M, Tokudome S, Kuratsune M. 1988. A 
case-control study of gastric cancer and diet in northern Kyushu, Japan. Jpn J Cancer Res 79: 1067-1074.

16) Kono S, Imanishi K, Shinchi K, Yanai F. 1993. Relationship of diet to small and large adenomas of the sigmoid colon. Jpn J Cancer Res 84: 13-19.

17) Kato I, Tominaga S, Matsumoto K. 1992. A prospective study of stomach cancer among a rural Japanese population. A 6-year survey. Jpn J Cancer Res 83: 568-575.

18) Hirose K, Tajima K, Hamajima N, Inoue M, Takezaki T, Kuroishi T, Yoshida M, Tokudome S. 1995. A largescale, hospital-based case-control study of risk factors of breast cancer according to menopausal status. Jpn J Cancer Res 86: 146-154.

19) Nishi M, Yoshida K, Hirata K, Miyake H. 1997. Eating habits and colorectal cancer. Oncol Rep 4: 995-998.

20) Sasazuki S, the Fukuoka Heart Study Group. 2001. Case-control study of nonfatal myocardial infarction in relation to selected foods in Japanese men and women. Jpn Circ J 65: 200-206.

21) Hirayama T. 1990. Life-Style and Mortality. A LargeScale Census-Based Cohort Study in Japan. Karger, Basel.

22) Wakai K, Egami I, Kato K, Lin Y, Kawamura T, Tamakoshi A, Aoki R, Kojima M, Nakayama T, Wada M, Ohno Y. 1999. A simple food frequency questionnaire for Japanese diet. Part I. Development of the questionnaire, and reproducibility and validity for food groups. J Epidemiol 9: 216-226.

23) Tokudome S, Imaeda $\mathrm{N}$, Tokudome $\mathrm{Y}$, Fujiwara $\mathrm{N}$, Nagaya T, Sato J, Kuriki K, Ikeda M, Maki S. 2001. Relative validity of a semi-quantitative food frequency questionnaire versus 28 day weighed diet records in Japanese female dietitians. Eur J Clin Nutr 55: 735742.

24) Date C, Yamaguchi M, Tanaka H. 1996. Development of a food frequency questionnaire in Japan. J Epidemiol 6 (Suppl 3): S131-S136.

25) Tsubono Y, Takamori S, Kobayashi M, Takahashi T, Iwase Y, Litoi Y, Akabane M, Yamaguchi M, Tsugane S. 1996. A data-based approach for designing a semiquantitative food frequency questionnaire for a population-based prospective study in Japan. J Epidemiol 6: $45-53$.

26) Egami I, Wakai K, Kato K, Lin Y, Kawamura T, Tamakoshi A, Aoki R, Kojima M, Nakayama T, Wada M, Ohno Y. 1999. A simple food frequency questionnaire for Japanese diet. Part II. Reproducibility and validity for nutrient intakes. J Epidemiol 9: 227-234.
27) Nishii T, Kono S, Abe H, Eguchi H, Shimazaki K, Hatano B, Hamada H. 2001. Glucose intolerance, plasma insulin levels, and colon adenomas in Japanese men. Jpn J Cancer Res 92: 836-840.

28) Kono S, Handa K, Hayabuchi H, Kiyohara $\mathrm{C}$, Inoue $\mathrm{H}$, Marugame T, Shinomiya S, Hamada H, Onuma K, Koga H. 1999. Obesity, weight gain and risk of colon adenomas in Japanese men. Jpn J Cancer Res 90: 805-811.

29) Kono S, Honjo S, Todoroki I, Nishiwaki M, Hamada H, Nishikawa H, Koga H, Ogawa S, Nakagawa K. 1998. Glucose intolerance and adenomas of the sigmoid colon in Japanese men (Japan). Cancer Causes Control 9: 441446.

30) Ministry of Health and Welfare, Japan. 2000. A Report of the National Nutrition Survey, in 1998. Dai-ichi Shuppan, Tokyo (in Japanese).

31) Science and Technology Agency, Japan. 1995. Standard Tables of Food Composition in Japan, Fourth revised edition. Printing Bureau of the Ministry of Finance, Tokyo (in Japanese).

32) Science and Technology Agency, Japan. 2000 Standard Tables of Food Composition in Japan, Fifth revised edition. Printing Bureau of the Ministry of Finance, Tokyo (in Japanese).

33) Shirota T, Yoshizumi F. 1990. A study on convenient dietary assessment. Nippon Koshu-eisei Gakkaishi (Jpn J Public Health) 37: 100-108 (in Japanese).

34) Fukuoka Prefectural Association of Dietitians. 1998. Essentials and Practice of Hospital Meal Service. Fukuoka Prefecture Association of Dietitians, Fukuoka (in Japanese).

35) Kagawa Nutrition University Publishing Division. 1996. Foods: Quick Guide for Energy and Salt Intake from Usual Portion Sizes. Kagawa Nutrition University Publishing Division, Tokyo (in Japanese)

36) Kagawa Nutrition University Publishing Division. 1986. Guidebook for Energy, Salt, and Protein of 640 Types of Everyday Side Dish. Kagawa Nutrition University Publishing Division, Tokyo (in Japanese).

37) Yamazaki K, Shimada K. 1983. Cookery and Its Theory, Second edition. Dobunshoin, Tokyo (in Japanese).

38) Willett WC, Stampfer MJ. 1986. Total energy intake. Implications for epidemiologic analyses. Am J Epidemiol 124: 17-27.

39) Tokudome $Y$, Imaeda N, Ikeda M, Kitagawa I, Fujiwara N, Tokudome S. 1999. Foods contributing to absolute intake and variance in intake of fat, fatty acids and cholesterol in middle-aged Japanese. J Epidemiol 9: 78-90. 
Appendix 1: Content of the dietary questionnaire

\section{Part 1. Alcoholic beverages}

Alcohol use (frequency and amount by type): Please answer, based on average consumption in the past year, by checking the appropriate box.

飲酒（種類別の頻度と量）：この1年間を平均して，あてはまるところに（ノ）をつけてください.

\begin{tabular}{|c|c|c|c|c|c|c|c|}
\hline & $\begin{array}{c}\text { No use } \\
\text { 飲まない }\end{array}$ & $\begin{array}{c}1-3 \text { times } \\
\text { per month } \\
\text { 月 } 1 \sim 3 \text { 回 }\end{array}$ & $\begin{array}{l}\text { 1-2 times } \\
\text { per week } \\
\text { 週1 2回 }\end{array}$ & $\begin{array}{l}\text { 3-4 times } \\
\text { per week } \\
\text { 週3 4回 }\end{array}$ & $\begin{array}{l}\text { 5-6 times } \\
\text { per week } \\
\text { 週5 6回 }\end{array}$ & $\begin{array}{l}\text { Daily } \\
\text { 毎日 }\end{array}$ & $\begin{array}{c}\text { Amount per } \\
\text { occasion } \\
1 \text { 回の量 }\end{array}$ \\
\hline $\begin{array}{l}\text { Sake } \\
\text { 日本酒 }\end{array}$ & $\square$ & $\square$ & $\square$ & $\square$ & $\square$ & $\square$ & ( ) 合 \\
\hline $\begin{array}{l}\text { Shochu } \\
\text { 焼酎 }\end{array}$ & $\square$ & $\square$ & $\square$ & $\square$ & $\square$ & $\square$ & ( ) 合 \\
\hline $\begin{array}{l}\text { Beer } \\
\text { ビール }\end{array}$ & $\square$ & $\square$ & $\square$ & $\square$ & $\square$ & $\square$ & $\begin{array}{l}\text { bottles } \\
(\text { )本 }\end{array}$ \\
\hline $\begin{array}{l}\text { Spirits } \\
\text { ウィスキー類 }\end{array}$ & $\square$ & $\square$ & $\square$ & $\square$ & $\square$ & $\square$ & $\begin{array}{c}\text { glasses } \\
(\quad) \text { 杯 }\end{array}$ \\
\hline $\begin{array}{l}\text { Wine } \\
\text { ワイン }\end{array}$ & $\square$ & $\square$ & $\square$ & $\square$ & $\square$ & $\square$ & $\begin{array}{c}\text { glasses } \\
(\quad) \text { 杯 }\end{array}$ \\
\hline
\end{tabular}

Specify bottle or can for the amount of beer:

large bottle $(633 \mathrm{~mL}) \quad$ medium-sized bottle $(500 \mathrm{~mL})$

large can $(500 \mathrm{~mL})$

medium-sized can $(350 \mathrm{~mL})$ small bottle $(233 \mathrm{~mL})$ small can $(250 \mathrm{~mL})$

Sake, Shochu: $1 \mathrm{go}=180 \mathrm{~mL}$

Whiskey: $\quad 1$ glass $=30 \mathrm{~mL}$

Wine: $\quad 1$ glass $=100 \mathrm{~mL}$

ビールの量はビン・カン，大・中・小を明記のこと

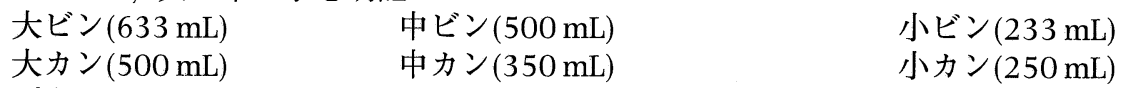

日本酒・焼酎 1 杯 $=180 \mathrm{~mL}$

ウィスキー 1 杯 $=30 \mathrm{~mL}$

ワイン 1 杯 $=100 \mathrm{~mL}$

\section{Part 2. Food items}

Please answer, based on average consumption in the past year regarding your usual diet, by marking the appropriate choice.

日常の食事について，この1年間を平均して答えてください。だいたいこの程度と思うところに（ノ）をつけてくださ い.

Staple foods: Please specify the amount consumed per day if you eat the item once or more per week. Specify the amount of rice as the number of medium-sized bowls.

主食：週 1 回以上食べる場合には, 食べる日あたりの量も記入してください.ご飯は普通の茶わんの杯数で記入して ください.

\begin{tabular}{|c|c|c|c|c|c|c|}
\hline & $\begin{array}{c}\text { Almost null } \\
\text { ほとんど食べない }\end{array}$ & $\begin{array}{l}1 \text { time/week } \\
\text { 週に1回 }\end{array}$ & $\begin{array}{c}\text { 2-3 times/week } \\
\text { 週に2 3回 }\end{array}$ & $\begin{array}{c}\text { 4-5 times/week } \\
\text { 週に4〜5回 }\end{array}$ & $\begin{array}{l}\text { Almost daily } \\
\text { ほぼ毎日 }\end{array}$ & $\begin{array}{c}\text { Amount } \\
\text { 量 }\end{array}$ \\
\hline $\begin{array}{l}\text { Boiled rice } \\
\text { ごはん }\end{array}$ & $\square$ & $\square$ & $\square$ & $\square$ & $\square$ & $\begin{array}{r}\text { bowls/d } \\
\text { ( }) \text { 杯/日 }\end{array}$ \\
\hline $\begin{array}{l}\text { Noodles } \\
\text { めん類 }\end{array}$ & $\square$ & $\square$ & $\square$ & $\square$ & $\square$ & $\begin{array}{r}\text { bowls/d } \\
\text { ( ) 杯/日 }\end{array}$ \\
\hline $\begin{array}{l}\text { Bread } \\
\text { パン }\end{array}$ & $\square$ & $\square$ & $\square$ & $\square$ & $\square$ & $\begin{array}{r}\text { slices/d } \\
\text { ( ) 枚/日 }\end{array}$ \\
\hline
\end{tabular}




\section{Supplementary food items}

副食

\begin{tabular}{|c|c|c|c|c|c|c|}
\hline \multicolumn{2}{|c|}{$\begin{array}{c}\text { Almost null } \\
\text { ほとんど食べない }\end{array}$} & \multirow{2}{*}{$\begin{array}{c}\begin{array}{c}1 \text { time/week } \\
\text { 週に1回 }\end{array} \\
\square\end{array}$} & \multirow{2}{*}{$\begin{array}{c}\begin{array}{c}2-3 \text { times/week } \\
\text { 週に2 3回 }\end{array} \\
\square\end{array}$} & \multirow{2}{*}{$\begin{array}{c}\begin{array}{c}4-5 \text { times/week } \\
\text { 週に4 5回 }\end{array} \\
\square\end{array}$} & \multirow{2}{*}{$\begin{array}{c}\text { Almost daily } \\
\text { ほぼ毎日 }\end{array}$} & \multirow{2}{*}{$\begin{array}{c}\begin{array}{c}2+/ \text { day } \\
\text { 毎日2回以上 }\end{array} \\
\square\end{array}$} \\
\hline $\begin{array}{l}\text { Butter } \\
\text { バター }\end{array}$ & $\square$ & & & & & \\
\hline $\begin{array}{l}\text { Margarine } \\
\text { マーガリン }\end{array}$ & $\square$ & $\square$ & $\square$ & $\square$ & $\square$ & $\square$ \\
\hline $\begin{array}{l}\text { Jam/honey } \\
\text { ジャム・はちみつ }\end{array}$ & $\square$ & $\square$ & $\square$ & $\square$ & $\square$ & $\square$ \\
\hline $\begin{array}{l}\text { Confectioneries } \\
\text { 菓子類 }\end{array}$ & $\square$ & $\square$ & $\square$ & $\square$ & $\square$ & $\square$ \\
\hline $\begin{array}{l}\text { Soft drinks } \\
\text { 甘い飲料 }\end{array}$ & $\square$ & $\square$ & $\square$ & $\square$ & $\square$ & $\square$ \\
\hline $\begin{array}{l}\text { Fish } \\
\text { 魚 }\end{array}$ & $\square$ & $\square$ & $\square$ & $\square$ & $\square$ & $\square$ \\
\hline $\begin{array}{l}\text { Poultry } \\
\text { とり肉 }\end{array}$ & $\square$ & $\square$ & $\square$ & $\square$ & $\square$ & $\square$ \\
\hline $\begin{array}{l}\text { Beef } \\
\text { 牛肉 }\end{array}$ & $\square$ & $\square$ & $\square$ & $\square$ & $\square$ & $\square$ \\
\hline $\begin{array}{l}\text { Pork } \\
\text { 豚肉 }\end{array}$ & $\square$ & $\square$ & $\square$ & $\square$ & $\square$ & $\square$ \\
\hline $\begin{array}{l}\text { Ham/sausage } \\
\text { ハム・ソーセージ }\end{array}$ & $\square$ & $\square$ & $\square$ & $\square$ & $\square$ & $\square$ \\
\hline $\begin{array}{l}\text { Eggs } \\
\text { 卵 }\end{array}$ & $\square$ & $\square$ & $\square$ & $\square$ & $\square$ & $\square$ \\
\hline $\begin{array}{l}\text { Milk } \\
\text { 牛乳 }\end{array}$ & $\square$ & $\square$ & $\square$ & $\square$ & $\square$ & $\square$ \\
\hline $\begin{array}{l}\text { Cheese } \\
\text { チーズ }\end{array}$ & $\square$ & $\square$ & $\square$ & $\square$ & $\square$ & $\square$ \\
\hline 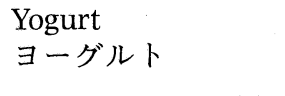 & $\square$ & $\square$ & $\square$ & $\square$ & $\square$ & $\square$ \\
\hline $\begin{array}{l}\text { Miso soup } \\
\text { みそ汁 }\end{array}$ & $\square$ & $\square$ & $\square$ & $\square$ & $\square$ & $\square$ \\
\hline $\begin{array}{l}\text { Tofu } \\
\text { 豆腐 }\end{array}$ & $\square$ & $\square$ & $\square$ & $\square$ & $\square$ & $\square$ \\
\hline $\begin{array}{l}\text { Fermented soybean } \\
\text { 納豆 }\end{array}$ & $\square$ & $\square$ & $\square$ & $\square$ & $\square$ & $\square$ \\
\hline
\end{tabular}


Vegetables, fruits, etc.

野菜・果物など

\begin{tabular}{|c|c|c|c|c|c|c|}
\hline \multicolumn{2}{|c|}{$\begin{array}{c}\text { Almost null } \\
\text { ほとんど食べない }\end{array}$} & \multirow{2}{*}{$\begin{array}{c}1 \text { time/week } \\
\text { 週に1回 }\end{array}$} & \multirow{2}{*}{$\frac{\begin{array}{c}2-3 \text { times/week } \\
\text { 週に2 3回 }\end{array}}{\square}$} & \multirow{2}{*}{$\frac{\begin{array}{c}4-5 \text { times/week } \\
\text { 週に4 5回 }\end{array}}{\square}$} & \multirow{2}{*}{$\begin{array}{c}\begin{array}{c}\text { Almost daily } \\
\text { ほぼ毎日 }\end{array} \\
\square\end{array}$} & \multirow{2}{*}{$\begin{array}{c}2+/ \text { day } \\
\text { 毎日2回以上 } \\
\square\end{array}$} \\
\hline $\begin{array}{l}\text { Green-yellow vegetables } \\
\text { 緑黄色野菜 }\end{array}$ & $\square$ & & & & & \\
\hline $\begin{array}{l}\text { Other vegetables } \\
\text { 淡色野菜 }\end{array}$ & $\square$ & $\square$ & $\square$ & $\square$ & $\square$ & $\square$ \\
\hline $\begin{array}{l}\text { Onions } \\
\text { たまねぎ }\end{array}$ & $\square$ & $\square$ & $\square$ & $\square$ & $\square$ & $\square$ \\
\hline $\begin{array}{l}\text { Garlic } \\
\text { にんにく }\end{array}$ & $\square$ & $\square$ & $\square$ & $\square$ & $\square$ & $\square$ \\
\hline $\begin{array}{l}\text { Pickles } \\
\text { 漬物 }\end{array}$ & $\square$ & $\square$ & $\square$ & $\square$ & $\square$ & $\square$ \\
\hline $\begin{array}{l}\text { Seaweeds } \\
\text { 藻類 (ワカメなど) }\end{array}$ & $\square$ & $\square$ & $\square$ & $\square$ & $\square$ & $\square$ \\
\hline $\begin{array}{l}\text { Apples } \\
\text { りんご }\end{array}$ & $\square$ & $\square$ & $\square$ & $\square$ & $\square$ & $\square$ \\
\hline $\begin{array}{l}\text { Oranges } \\
\text { みかん類 }\end{array}$ & $\square$ & $\square$ & $\square$ & $\square$ & $\square$ & $\square$ \\
\hline $\begin{array}{l}\text { Other fruits } \\
\text { 他の果物 }\end{array}$ & $\square$ & $\square$ & $\square$ & $\square$ & $\square$ & $\square$ \\
\hline $\begin{array}{l}\text { Mayonnaise } \\
\text { マヨーズ }\end{array}$ & $\square$ & $\square$ & $\square$ & $\square$ & $\square$ & $\square$ \\
\hline $\begin{array}{l}\text { Dressing } \\
\text { ドレッシング }\end{array}$ & $\square$ & $\square$ & $\square$ & $\square$ & $\square$ & $\square$ \\
\hline $\begin{array}{l}\text { Deep-fried foods } \\
\text { 揚げ物 }\end{array}$ & $\square$ & $\square$ & $\square$ & $\square$ & $\square$ & $\square$ \\
\hline $\begin{array}{l}\text { Pan-fried foods } \\
\text { 炒め物 }\end{array}$ & $\square$ & $\square$ & $\square$ & $\square$ & $\square$ & $\square$ \\
\hline
\end{tabular}

\section{Tea and coffee}

お茶とコーヒー

\begin{tabular}{|c|c|c|c|c|c|c|}
\hline & $\begin{array}{c}\text { Almost null } \\
\text { ほとんど飲まない }\end{array}$ & $\begin{array}{c}1 \text { cup/week } \\
\text { 週に1杯 }\end{array}$ & $\begin{array}{c}2-3 \text { cups/week } \\
\text { 週に2 3杯 }\end{array}$ & $\begin{array}{c}4-5 \text { cups/week } \\
\text { 週に4 5杯 }\end{array}$ & $\begin{array}{l}\text { Almost daily } \\
\text { ほぼ毎日 }\end{array}$ & $\begin{array}{c}\text { Amount } \\
\text { 量 }\end{array}$ \\
\hline $\begin{array}{l}\text { Green tea } \\
\text { 緑茶 }\end{array}$ & $\square$ & $\square$ & $\square$ & $\square$ & $\square$ & $\begin{array}{l}\text { cups/d } \\
\text { ( ) 杯/日 }\end{array}$ \\
\hline $\begin{array}{l}\text { Coffee } \\
\text { コーヒー }\end{array}$ & $\square$ & $\square$ & $\square$ & $\square$ & $\square$ & $\begin{array}{l}\text { cups/d } \\
\text { ( ) 杯/ }\end{array}$ \\
\hline
\end{tabular}

\section{Main foods selected special foods}

調理品

\begin{tabular}{|c|c|c|c|c|c|c|}
\hline & $\begin{array}{l}\text { Almost null } \\
\text { ほとんど食べない }\end{array}$ & $\begin{array}{c}1 \text { time/week } \\
\text { 週に1回 }\end{array}$ & $\begin{array}{c}\text { 2-3 times/week } \\
\text { 週に2 3回 }\end{array}$ & $\begin{array}{l}\text { 4-5 times/week } \\
\text { 週に4〜5回 }\end{array}$ & $\begin{array}{l}\text { Almost daily } \\
\text { ほぼ毎日 }\end{array}$ & $\begin{array}{c}2+/ \text { day } \\
\text { 毎日2回以上 }\end{array}$ \\
\hline $\begin{array}{l}\text { Broiled fish } \\
\text { 焼き魚 }\end{array}$ & $\square$ & $\square$ & $\square$ & $\square$ & $\square$ & $\square$ \\
\hline $\begin{array}{l}\text { Broiled meat } \\
\text { 焼き肉 }\end{array}$ & $\square$ & $\square$ & $\square$ & $\square$ & $\square$ & $\square$ \\
\hline $\begin{array}{l}\text { Broiled poultry } \\
\text { 焼き鳥 }\end{array}$ & $\square$ & $\square$ & $\square$ & $\square$ & $\square$ & $\square$ \\
\hline $\begin{array}{l}\text { Raw vegetables } \\
\text { 生野菜 }\end{array}$ & $\square$ & $\square$ & $\square$ & $\square$ & $\square$ & $\square$ \\
\hline $\begin{array}{l}\text { Chinese dumpling } \\
\text { ぎょうざ }\end{array}$ & $\square$ & $\square$ & $\square$ & $\square$ & $\square$ & $\square$ \\
\hline
\end{tabular}


Appendix 2: Food items in the food frequency questionnaire and corresponding foods in the Food Composition Table used for estimating nutrient intake ${ }^{1}$

\begin{tabular}{|c|c|c|}
\hline Food item & Portion (g) & Food in the Food Composition Table \\
\hline Steamed rice & 140 & cooked paddy rice [142d] \\
\hline Noodles & 200 & udon [121b] (0.8), Chinese noodle [128a] (0.2) \\
\hline Bread & 120 & white bread [113a] (0.62), soft rolls [11319] (0.38) \\
\hline Butter & 7 & butter $[1128]$ \\
\hline Margarine & 7 & margarine [57] \\
\hline Jam/honey & 7 & $\begin{array}{l}\text { strawberries [137] }(0.24) \text {, apples [1391] (0.24), grape [1374] (0.24), } \\
\text { honey [316] (0.28) }\end{array}$ \\
\hline Confectioneries $^{2}$ & $50^{3}$ & $\begin{array}{l}\text { custard pudding [443] (0.3), Japanese cake [424e] }(0.13) \text {, jam bun [456] }(0.11) \text {, } \\
\text { Danish pastry [458] }(0.10) \text {, bean-jam bun [454] }(0.12), \\
\text { chocolate-cornet [457] (0.16), snack cake [463] (0.08) }\end{array}$ \\
\hline Sweet beverages & $180^{3}$ & $\begin{array}{l}\text { carbonated beverages [1633a] }(0.25) \text {, cola }[1633 \mathrm{~b}](0.25) \text {, } \\
\text { grapefruit juice }[1338 \mathrm{~d}](0.25) \text {, apple juice }[1389 \mathrm{e}](0.25)\end{array}$ \\
\hline Fish & 70 & $\begin{array}{l}\text { fish paste products [8246] }(0.23) \text {, sea bream [8110a] }(0.2) \text {, } \\
\text { mackerel [884a] }(0.19) \text {, sardine [826a] }(0.15) \text {, tuna [8149] }(0.13) \text {, } \\
\text { fish sausage [8258] }(0.1)\end{array}$ \\
\hline Poultry ${ }^{4}$ & 50 & chicken breast [947a] (0.5), chicken thigh [949a] (0.5) \\
\hline Beef $^{4}$ & 70 & sirloin [912a] (0.5), rump [920b] (0.5) \\
\hline Pork $^{4}$ & 70 & loin $[968 b](0.5)$, belly [969b] $(0.5)$ \\
\hline Ham/sausage & $20^{3}$ & loin $[986 c](0.5)$, mixed $[987 \mathrm{~h}](0.5)$ \\
\hline Eggs & 50 & chicken egg [105a] \\
\hline Milk & 180 & ordinary milk [112] \\
\hline Cheese & 24 & process cheese [1123] \\
\hline Yogurt & 100 & yogurt [119a] \\
\hline Miso soup & 15 & rice-koji miso [732a] \\
\hline Tofu & 100 & soybean curd [721a] \\
\hline Fermented soybean & 50 & natto $[729]$ \\
\hline $\begin{array}{l}\text { Green-yellow } \\
\text { vegetables }\end{array}$ & 75 & $\begin{array}{l}\text { tomato [1285] }(0.45), \text { carrot }[1294 a](0.35), \\
\text { green pepper [12108a] }(0.15) \text {, others }(0.05)\end{array}$ \\
\hline Other vegetables & 150 & $\begin{array}{l}\text { cucumber }[1225 a](0.28) \text {, cabbage }[1224 a](0.22) \text {, eggplant }[1287 a](0.2) \text {, } \\
\text { Japanese radish }[1256 a](0.18) \text {, onion [1270a] }(0.12)\end{array}$ \\
\hline Garlic & 5 & garlic [1295] \\
\hline Pickled vegetables & 20 & Chinese cabbage [12101b] \\
\hline Seaweed & 2 & dried seaweed (wakame) [1535a] \\
\hline Apple & $180^{3}$ & apple [1388] \\
\hline Citrus fruits $^{2}$ & $100^{3}$ & $\begin{array}{l}\text { mandarin }[1317 \mathrm{~b}](0.6), \text { natsumikan }[1354](0.18), \text { iyokan }[1311](0.11) \text {, } \\
\text { hassaku [1362] (0.11) }\end{array}$ \\
\hline Other fruits ${ }^{2}$ & $100^{3}$ & banana [1364] (0.85), watermelon [1345] (0.11), strawberry [136] (0.04) \\
\hline Mayonnaise & 10 & mayonnaise (egg-yolk type) [1710b] \\
\hline Salad dressing & 10 & salad dressing $[179 \mathrm{a}]$ \\
\hline Deep-fried foods ${ }^{5}$ & 10 & vegetables oils [51] \\
\hline Pan-fried foods ${ }^{5}$ & 5 & vegetables oils [51] \\
\hline Chinese dumpling ${ }^{5}$ & 180 & $\begin{array}{l}\text { pork belly [969b] }(0.19) \text {, cabbage }[1224 a](0.22) \text {, garlic [1295] }(0.01) \text {, } \\
\text { welsh onion [1296] }(0.08) \text {, uncounted }(0.5)\end{array}$ \\
\hline Green tea & $100^{3}$ & green-tea infusion [1621b] \\
\hline Coffee & $150^{3}$ & brewed coffee [1630b] \\
\hline
\end{tabular}

In parentheses are proportions of each food used to calculate nutrients. Codes in brackets stand for food codes in the Food Composition Table.

1 Unless otherwise specified, portion sizes and proportions of composite foods are based on a previous survey conducted by Shirota and Yoshizumi (33).

2 Proportions of composite foods are based on data compiled by the Fukuoka Prefectural Association of Dietitians (34).

3 Determined on the basis of commonly used portion or serving sizes (35). Common individual foods were assigned to items of sweet beverages and ham/sausage with equal proportions.

4 Portion sizes are based on a previous survey (33), and proportions of composite foods were determined on the basis of commonly used recipes $(36,37)$.

${ }^{5}$ Both portion sizes and proportions of composite foods were determined on the basis of commonly used recipes $(36,37)$. 